\title{
Hydrolysed Collagen from Sheepskins as a Source of Functional Peptides with Antioxidant Activity
}

\author{
Arely León-López ${ }^{1}$, Lucía Fuentes-Jiménez ${ }^{2}$, Alma Delia Hernández-Fuentes ${ }^{1}$, \\ Rafael G. Campos-Montiel ${ }^{1}$ and Gabriel Aguirre-Álvarez ${ }^{1, *} \mathbb{B}$ \\ 1 Universidad Autónoma del Estado de Hidalgo, Instituto de Ciencias Agropecuarias, Av. Universidad Km. 1 \\ Rancho Universitario, Tulancingo, Hidalgo 43600, Mexico \\ 2 Instituto Tecnológico Superior del Oriente del Estado de Hidalgo, Carretera Apan-Tepeapulco Km 3.5, Las \\ Peñitas, Ápan, Hidalgo 43900, Mexico \\ * Correspondence: aguirre@uaeh.edu.mx; Tel.: +52-775-145-9265
}

Received: 5 July 2019; Accepted: 29 July 2019; Published: 13 August 2019

\begin{abstract}
The extraction and enzymatic hydrolysis of collagen from sheepskins at different times of hydrolysis $(0,10,15,20,30 \mathrm{~min}, 1,2,3$ and $4 \mathrm{~h}$ ) were investigated in terms of amino acid content (hydroxyproline), isoelectric point, molecular weight $(\mathrm{Mw})$ by sodium dodecyl sulphate polyacrylamide gel electrophoresis (SDS-PAGE) method, viscosity, Fourier-transform infrared (FTIR) spectroscopy, antioxidant capacity by $2,2^{\prime}$-azino-bis(3-ethylbenzothiazoline-6-sulphonic acid) (ABTS) and 2,2-diphenyl-1-picrylhydrazyl (DPPH) assays, thermal properties (Differential Scanning Calorimetry) and morphology by scanning electron microscopy (SEM) technique. The kinetics of hydrolysis showed an increase in the protein and hydroxyproline concentration as the hydrolysis time increased to $4 \mathrm{~h}$. FTIR spectra allowed us to identify the functional groups of hydrolysed collagen (HC) in the amide I region for collagen. The isoelectric point shifted to lower values compared to the native collagen precursor. The change in molecular weight and viscosity from time 0 min to $4 \mathrm{~h}$ promoted important antioxidant activity in the resulting $\mathrm{HC}$. The lower the $\mathrm{Mw}$, the greater the ability to donate an electron or hydrogen to stabilize radicals. From the SEM images it was evident that $\mathrm{HC}$ after $2 \mathrm{~h}$ had a porous and spongy structure. These results suggest that $\mathrm{HC}$ could be a good alternative to replace $\mathrm{HC}$ from typical sources like pigs, cows and fish.
\end{abstract}

Keywords: collagen; hydrolysis; enzyme; molecular weight; sheepskin

\section{Introduction}

Collagen is the most abundant protein in bones and connective tissue in vertebrates, and there are at least 29 types. They are different in terms of their amino acid sequence and composition, the function in the organism, and the structure [1,2]. The structure of collagen is a triple helix formed for $3 \alpha$ chains Gly-X-Y, where $X$ is proline, $Y$ is mainly hydroxyproline, and the triple helix is stabilized for hydrogen bonds with continuous repetition of the Gly-X-Y depending on the collagen type [3]. Collagen can be extracted from the skins, bones, tendons and cartilages of pigs [4], cows [5], marine organisms [6-8] and rabbits [9]. Hydrolysed collagen (HC) refers to a group of peptides that results from the proteolysis of native collagen type 1 ; its molecular weight $(\mathrm{Mw})$ varies from 0.3 to $8 \mathrm{KDa}$ [10]. It does not jellify in solution at room temperature and is soluble in cold water, so it can mix easily with other products [11-13]. Additionally, hydrolysed collagen has a neutral smell, is colourless, and can be used in emulsions as a stabilizer. It is widely used in the pharmaceutical industry for the treatment of diseases like osteoarthritis and osteoporosis. Also, in the cosmetics and food industries it is applied for the preparation of fruity beverages and nutritional supplements [14-17]. 
The antioxidant activity is the capacity of a substance to inhibit oxidative degradation by reacting with free radicals. There are natural antioxidants such as HC that exhibit mechanisms to exert antioxidant activity hydrogen transfer or electron donation [18]. The antioxidant activity of hydrolysed collagen is generally associated with the molecular weight. Peptides with 2 to 10 amino acid residues have a molecular weight of around $10 \mathrm{KDa}$. They show high radical scavenging because of their accessibility to active radicals. The amino acid content as well as the Mw of HC are properties closely related to the antioxidant activity $[19,20]$.

Several studies on antioxidant activity have been conducted with HC from different sources such as pigs [4,21], cows [22], fish [23-25], and invertebrates like jellyfishes or sponges [26,27]. However, less is known about the properties of hydrolysed collagen extracted from ovine sources and its possible applications. The objective of this research is the extraction and hydrolysis of collagen from sheepskins to establish the antioxidant activity as well as the physicochemical properties of the obtained peptides as a function of the hydrolysis time. These results could be of interest in developing an alternative source to fish, cows and pigs.

\section{Results and Discussion}

\subsection{Protein Content}

From Figure 1, it can be seen that the protein concentration of HC was affected by the hydrolysis time. Before hydrolysis (at $0 \mathrm{~min}$ ), the protein concentration was $1.61 \mathrm{mg} / \mathrm{mL}$. However, in the first $20 \mathrm{~min}$ the lowest concentration was reported, up to approximately $1.1 \mathrm{mg} / \mathrm{mL}$. The concentration remained constant around $1.21 \mathrm{mg} / \mathrm{mL}$ and there were no statistical differences $(p>0.05)$ from $30 \mathrm{~min}$ treatment to the end of the experiment $(4 \mathrm{~h})$. This behaviour could be due to the decrease in available substrate and/or enzyme autodigestion [28]. All the treatments in this experiment reported higher protein concentrations compared to those reported by Paul and co-workers [29]. They obtained hydrolysed collagen from cowhide using an enzymatic treatment. The protein concentration was reported with $0.11 \mathrm{mg} / \mathrm{mL}$. Other works [30] also obtained a low protein concentration (around $0.76 \mathrm{mg} / \mathrm{mL}$ ) from chicken connective tissue with enzymatic treatment at $\mathrm{pH}$ 7.5. These results suggest that hydrolysis of collagen from sheepskin under the conditions described above was efficient compared to chicken and bovine sources.

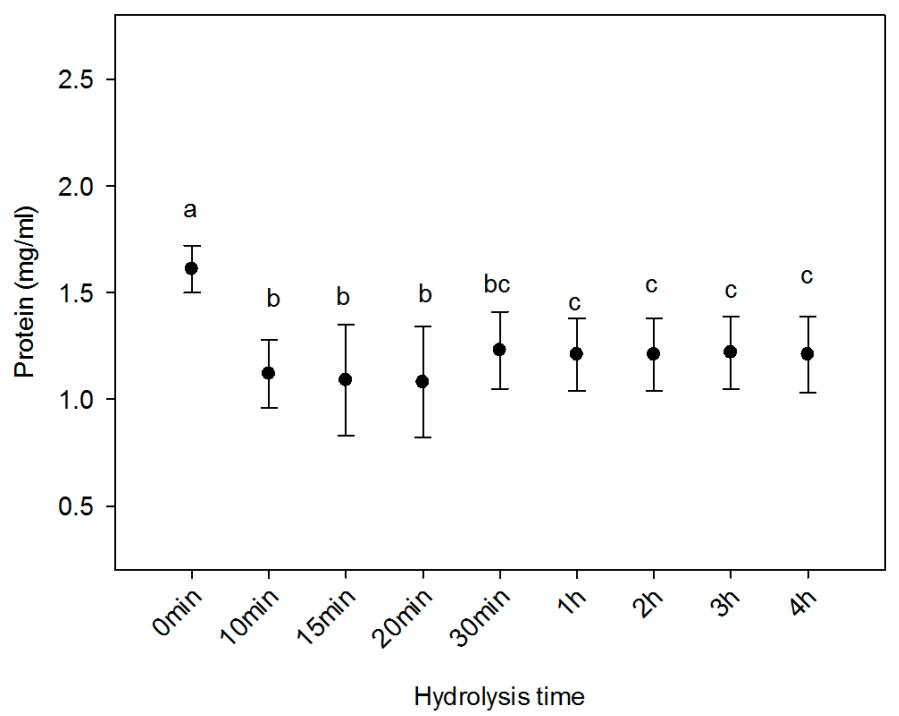

Figure 1. Protein concentration for different hydrolysis times in ovine collagen. Different letters represent the average of three replicates and indicate significant difference at $p \leq 0.05$. 


\subsection{Hydroxyproline Content}

Collagen is different from other proteins due to its high concentration of hydroxyproline. This amino acid provides thermal stability to collagen molecules because of the hydrogen bond formation and the presence of an hydroxyl group $(\mathrm{OH})$, limiting the rotation of the peptide chain $[15,31]$. The hydrolysis of collagen reported in Figure 2 indicates that the longer the hydrolysis time, the more hydroxyproline is obtained. After $4 \mathrm{~h}$ of enzymatic and thermal treatment, HC reported $24.47 \mathrm{mg} / \mathrm{L}$. This trend agrees well with previous works carried out on fish bone gelatine [32] and pig collagen [33]. They found a significant increment in hydroxyproline content as the hydrolysis time increased. Also, their maximum yield of this amino acid was found at $4 \mathrm{~h}$ of thermal treatment. This increment in hydroxyproline content could be attributed to the hydrolysis of the polypeptide chain. These thermal and enzymatic treatments increased the detectable amount of hydroxyproline. This could be the case with some marine sources like Atlantic salmon skin [34] and bigeye snapper skin [35], for which values of $88.24 \mathrm{mg} / \mathrm{mL}$ and $87.75-90.86 \mathrm{mg} / \mathrm{mL}$, respectively, were reported. However, Gómez-Lizárraga and co-workers [36] obtained $1.18 \mathrm{mg} / \mathrm{L}$ from bovine tendons.

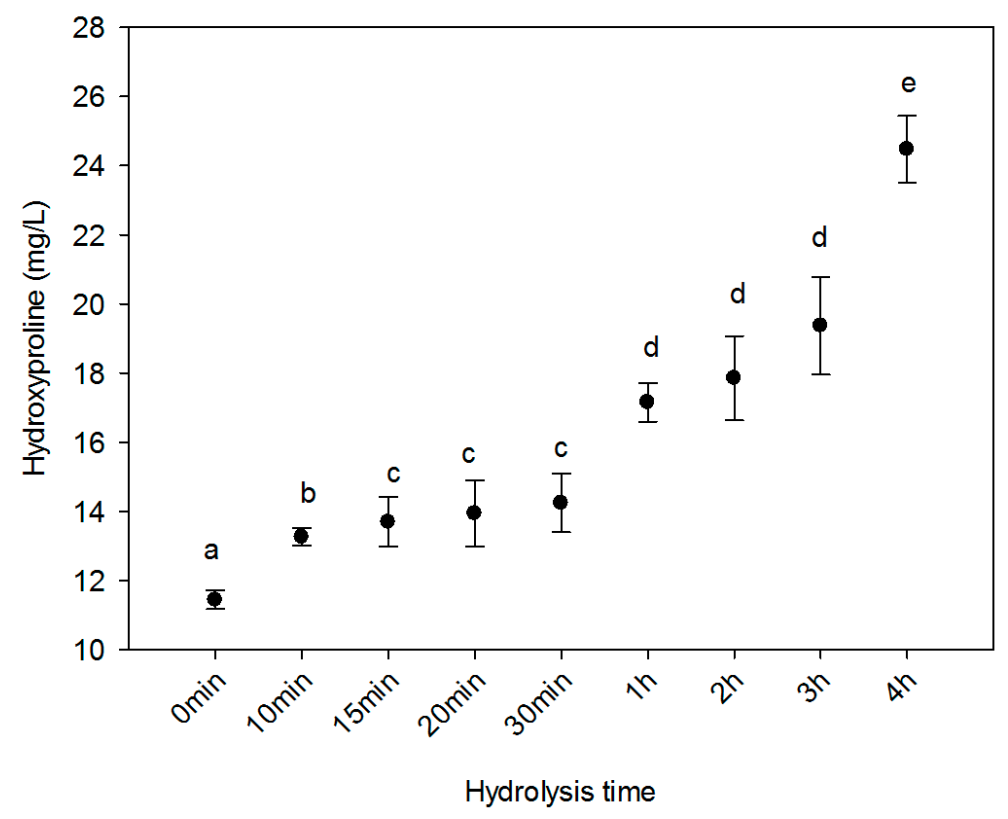

Figure 2. Hydroxyproline concentration in hydrolysed collagen. Different letters indicate significant difference at $p \leq 0.05$.

\subsection{Amino Acid Content in Hydrolysed Collagen as a Function of Hydrolysis Time}

The amino acid composition of hydrolysed collagen (HC) from sheepskin was very similar to other vertebrate collagen sources such as pigs [33], chicken [37], calves [38], cows [39] and fish [40]. Seventeen amino acids were identified and quantified as structural components of ovine collagen. These amino acids were monitored during the enzymatic hydrolysis process of collagen. Results after $1 \mathrm{~h}$ were not included in Table 1 because no significant differences $(p>0.05)$ were observed. After $1 \mathrm{~m}$ of hydrolysis, serine was detected as the major component $(19.33 \mathrm{mg} / \mathrm{g}$ of protein). The enzymatic treatment of collagen showed significant increments in aspartic acid and glutamic acid due to enzymatic cleavage of the polypeptide chains of collagen fibres [41]. These amino acids increased their concentrations considerably as a result of the deamidation process of asparagine and glutamine, respectively [42]. Some amino acids such as lysine, proline, cysteine, tyrosine, valine, methionine, isoleucine, leucine and phenylalanine were sensitive to hydrolysis and their concentrations decreased considerably. The same behaviour was observed with HC from fish skin [43]. 
Table 1. Amino acid content (mg of amino acid/g of protein) of hydrolysed collagen as a function of hydrolysis time.

\begin{tabular}{|c|c|c|c|c|c|}
\hline Amino Acid & $0 \mathrm{~min}$ & $10 \mathrm{~min}$ & $20 \mathrm{~min}$ & $30 \mathrm{~min}$ & $1 \mathrm{~h}$ \\
\hline Aspartic acid & $4.04 \pm 0.03^{a}$ & $10.86 \pm 0.05^{\mathrm{d}}$ & $5.06 \pm 0.04^{\mathrm{f}}$ & $28.03 \pm 0.036 \mathrm{~g}$ & $32.85 \pm 0.16^{a}$ \\
\hline Glutamic acid & $7.99 \pm 0.06^{\mathrm{a}}$ & $7.71 \pm 0.04^{\mathrm{a}}$ & $16.19 \pm 0.05^{\mathrm{e}}$ & $38.21 \pm 0.048^{f}$ & $16.58 \pm 0.03^{a}$ \\
\hline Serine & $19.33 \pm 0.16^{a}$ & $25.99 \pm 0.03^{c}$ & $17.45 \pm 0.03^{a}$ & $13.72 \pm 0.03^{\mathrm{a}}$ & $17.87 \pm 0.05^{a}$ \\
\hline Glycine & $4.86 \pm 0.01^{\mathrm{a}}$ & $4.31 \pm 0.04^{\mathrm{a}}$ & $16.71 \pm 0.04^{\mathrm{a}}$ & $1.92 \pm 0.00^{\mathrm{a}}$ & $3.10 \pm 0.00^{a}$ \\
\hline Lysine & $6.60 \pm 0.04^{\mathrm{a}}$ & $5.72 \pm 0.02^{\mathrm{a}}$ & $3.32 \pm 0.06^{\mathrm{a}}$ & $2.05 \pm 0.00^{\mathrm{a}}$ & $1.92 \pm 0.00^{\mathrm{a}}$ \\
\hline Histidine & $3.38 \pm 0.03^{a}$ & $3.25 \pm 0.05^{\mathrm{a}}$ & $2.41 \pm 0.01^{\mathrm{a}}$ & $3.95 \pm 0.02^{a}$ & $1.59 \pm 0.00^{\mathrm{a}}$ \\
\hline Threonine & $2.72 \pm 0.06^{\mathrm{a}}$ & $4.50 \pm 0.02^{\mathrm{a}}$ & $2.90 \pm 0.01^{\mathrm{a}}$ & $3.18 \pm 0.01^{\mathrm{a}}$ & $3.12 \pm 0.00^{a}$ \\
\hline Arginine & $8.91 \pm 0.01^{\mathrm{a}}$ & $3.46 \pm 0.05^{\mathrm{a}}$ & $18.62 \pm 0.03^{b}$ & $2.68 \pm 0.02^{\mathrm{a}}$ & $11.02 \pm 0.02^{a}$ \\
\hline Alanine & $1.39 \pm 0.04^{\mathrm{a}}$ & $0.40 \pm 0.04^{\mathrm{a}}$ & $1.26 \pm 0.00^{a}$ & $0.14 \pm 0.00^{\mathrm{a}}$ & $1.39 \pm 0.00^{a}$ \\
\hline Proline & $2.68 \pm 0.04^{\mathrm{a}}$ & $1.23 \pm 0.03^{\mathrm{a}}$ & $0.86 \pm 0.00^{\mathrm{a}}$ & $0.13 \pm 0.00^{\mathrm{a}}$ & $0.49 \pm 0.00^{\mathrm{a}}$ \\
\hline Cysteine & $1.53 \pm 0.02^{\mathrm{a}}$ & $1.84 \pm 0.03^{\mathrm{a}}$ & $1.00 \pm 0.00^{\mathrm{a}}$ & $0.13 \pm 0.00^{\mathrm{a}}$ & $0.36 \pm 0.00^{\mathrm{a}}$ \\
\hline Tyrosine & $12.36 \pm 0.18^{a}$ & $3.02 \pm 0.02^{d}$ & $7.24 \pm 0.05^{f}$ & $0.78 \pm 0.00 \mathrm{~g}$ & $2.9 \pm 0.01^{\mathrm{a}}$ \\
\hline Valine & $3.17 \pm 0.05^{\mathrm{a}}$ & $2.73 \pm 0.01^{\mathrm{a}}$ & $1.67 \pm 0.00^{\mathrm{a}}$ & $1.53 \pm 0.00^{\mathrm{a}}$ & $1.26 \pm 0.01^{\mathrm{a}}$ \\
\hline Methionine & $7.80 \pm 0.04^{\mathrm{a}}$ & $7.48 \pm 0.04^{\mathrm{a}}$ & $0.75 \pm 0.00^{\mathrm{c}}$ & $1.36 \pm 0.00^{\mathrm{d}}$ & $1.65 \pm 0.00^{\mathrm{a}}$ \\
\hline Isoleucine & $6.13 \pm 0.03^{a}$ & $6.49 \pm 0.05^{\mathrm{a}}$ & $0.52 \pm 0.00^{b}$ & $0.27 \pm 0.00^{c}$ & $1.21 \pm 0.00^{\mathrm{a}}$ \\
\hline Leucine & $3.41 \pm 0.01^{\mathrm{a}}$ & $6.35 \pm 0.03^{b}$ & $1.00 \pm 0.00^{\mathrm{d}}$ & $0.24 \pm 0.00^{\mathrm{e}}$ & $1.30 \pm 0.00^{\mathrm{a}}$ \\
\hline Phenylalanine & $2.66 \pm 0.07^{\mathrm{a}}$ & $3.31 \pm 0.04^{\mathrm{a}}$ & $1.66 \pm 0.00^{\mathrm{a}}$ & $0.87 \pm 0.00^{\mathrm{a}}$ & $0.69 \pm 0.00^{\mathrm{a}}$ \\
\hline
\end{tabular}

Results are mean values of three replicates' SD. Values followed by different letters are significantly different according to Tukey's test $(p \leq 0.05)$.

\subsection{Isoelectric Point}

Isoelectric point $(\mathrm{pI})$ is the $\mathrm{pH}$ of the collagen molecule at 0 charge. Looking at Figure 3 , the $\mathrm{pI}$ shifted from 4.61 to 3.68 at the end of the hydrolysis $(4 \mathrm{~h})$. Native collagen $(0 \mathrm{~min})$ reported a pI value of about 4.7. Similar values of $\mathrm{pI}$ for acid (4.9) and pepsin-soluble (5.7) collagen were reported in the literature on the extraction of collagen from ovine bones [1]. Hydrolysed collagen (HC) is an amphoteric macromolecule composed of both acidic $(\mathrm{COOH})$ and basic $\left(\mathrm{NH}_{3}\right)$ functional groups and the pI decrement could be due to the deamination process [10]. When HC was treated at high temperature, the asparagine groups transformed to aspartic acid and the glutamine groups into glutamic acid [42]. This leads to a loss of amino groups and a large relative increase in the carboxyl groups, or a higher content of acidic amino acids, which become dominant, shifting the $\mathrm{pI}$ to lower values [44,45]. Collagen is an amphoteric macromolecule that possesses different $\mathrm{pI}$ according to the hydrolysis time. The higher the pI, the higher the viscosity observed due to stronger electrostatic repulsions between collagen chains [46].

\subsection{Molecular Weight and Viscosity}

Hydrolysis of collagen is characterized by a reduction in its molecular weight $(\mathrm{Mw})$. Changes in collagen Mw were monitored by SDS-PAGE methodology. Figure 4 shows that native collagen ( $0 \mathrm{~min}$ ) reflected the highest $\mathrm{Mw}$ with $260.33 \mathrm{KDa}$. When the hydrolysis started, the Mw dropped to lower values. The first significant changes $(p \leq 0.05)$ were observed at $15 \mathrm{~min}$ and $20 \mathrm{~min}$ with 160.67 KDa and $138.89 \mathrm{KDa}$, respectively. However, there was a massive decrement in $\mathrm{Mw}$ after treatment for $2 \mathrm{~h}(15.20 \mathrm{KDa})$. After this time, no significant changes in Mw were registered $(p \geq 0.05)$ up to $4 \mathrm{~h}$ with $5.62 \mathrm{KDa}$. These results are in good agreement with those reported in the literature with values between 3 and $6 \mathrm{KDa}[11,13]$. Chi and co-workers [47] used trypsin for digestion to obtain fish hydrolysed collagen with $\mathrm{Mw}$ around $14 \mathrm{KDa}$. Also, hydrolysed collagen from turkey byproducts was obtained with Mw of $34 \mathrm{KDa}$ by using different enzymes [48]. Previous works carried out on Alaska Pollack skin [43] and sea cucumber [49] found high antioxidative properties in HC with Mw around 6-8 KDa and $5 \mathrm{KDa}$, respectively. There is a close relationship between the $\mathrm{Mw}$ and the viscosity of the collagen [12]. At $0 \mathrm{~min}$, the viscosity reported $6800 \mathrm{Cp}$. This higher viscosity could be attributed to the presence of high molecular weight and chains [50]. The viscosity decreased upon heating, in 
accordance with the hydrolysis time. It shifted to $0.5 \mathrm{Cp}$ when the hydrolysis had been going on for $1 \mathrm{~h}$. After this time, no significant changes $(p \geq 0.05)$ were observed. The triple helix structure of native collagen was changed to a random coil form due to the dissociation of the hydrogen bonds [51].

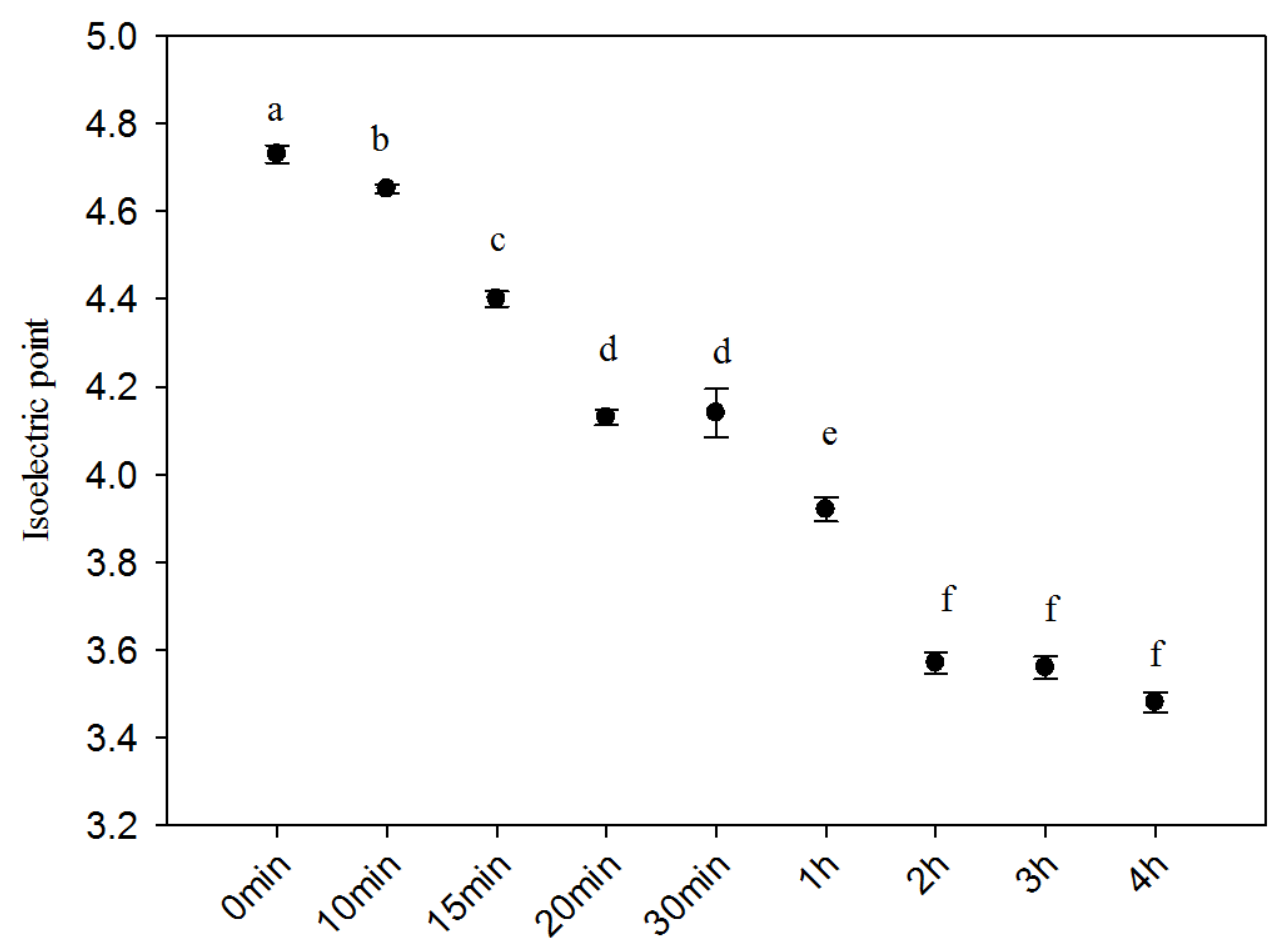

\section{Hydrolysis time}

Figure 3. Isoelectric point of ovine collagen hydrolysates as a function of hydrolysis time. Different letters indicate significant difference at $p \leq 0.05$.

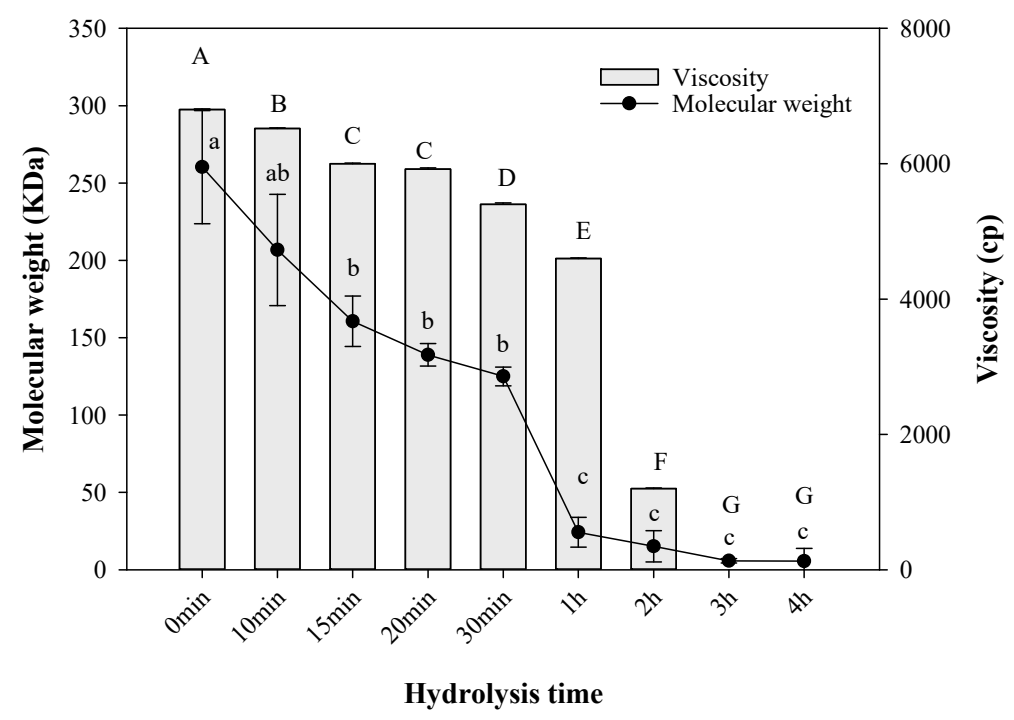

Figure 4. Co-relation between molecular weight and viscosity during the hydrolysis of ovine collagen. The different letters indicate significant difference at $p \leq 0.05$.

\subsection{Fourier Transform-Infrared Spectroscopy (FTIR)}

The FTIR spectra of both native collagen $(0 \mathrm{~min})$ and hydrolysed collagen $(\mathrm{HC})$ were produced in the range of $600-4000 \mathrm{~cm}^{-1}$. All FTIR spectra of HC samples overlapped each other. However, for 
reasons of clarity, Figure 5 only shows the range of $1000-3500 \mathrm{~cm}^{-1}$ for the samples at $0 \mathrm{~min}$ and $4 \mathrm{~h}$. There were no changes in peak location for the amide bands between the control and the treated sample. However, the magnitude of amplitude in $\mathrm{HC}$ decreased significantly. Amide I at wavelength $1641 \mathrm{~cm}^{-1}$ was interpreted as the stretching vibrations of the carbonyl groups $(\mathrm{C}=\mathrm{O})$ along the polypeptide backbone. This band is characteristic of $\alpha$-helix chains and is widely used to analyse the secondary structure of collagen [52]. Amide II was detected at $1548 \mathrm{~cm}^{-1}$ for the stretching vibrations of the CN group. Amide III was mainly associated with intermolecular interactions at $1248 \mathrm{~cm}^{-1}$, representing the stretching vibrations of the $\mathrm{C}-\mathrm{N}$ group and the deformation of the $\mathrm{NH}$ group from amide bonds [1]. The amide B $\left(2946 \mathrm{~cm}^{-1}\right)$ and Amide A $\left(3295 \mathrm{~cm}^{-1}\right)$ bands were related to the asymmetric stretching of the $\mathrm{CH}_{2}$ groups and vibrations of tension of the $\mathrm{NH}$ group, respectively. The longer the hydrolysis time, the higher the vibrations of $\mathrm{OH}$ groups $\left(1037 \mathrm{~cm}^{-1}\right)$ reported in the spectra. These results agree very well with the literature [7], suggesting that the HC $(1 \mathrm{~h})$ maintained the same characteristics of native collagen $(0 \mathrm{~min})$ as the peak locations of all amide bands scarcely caused changes.

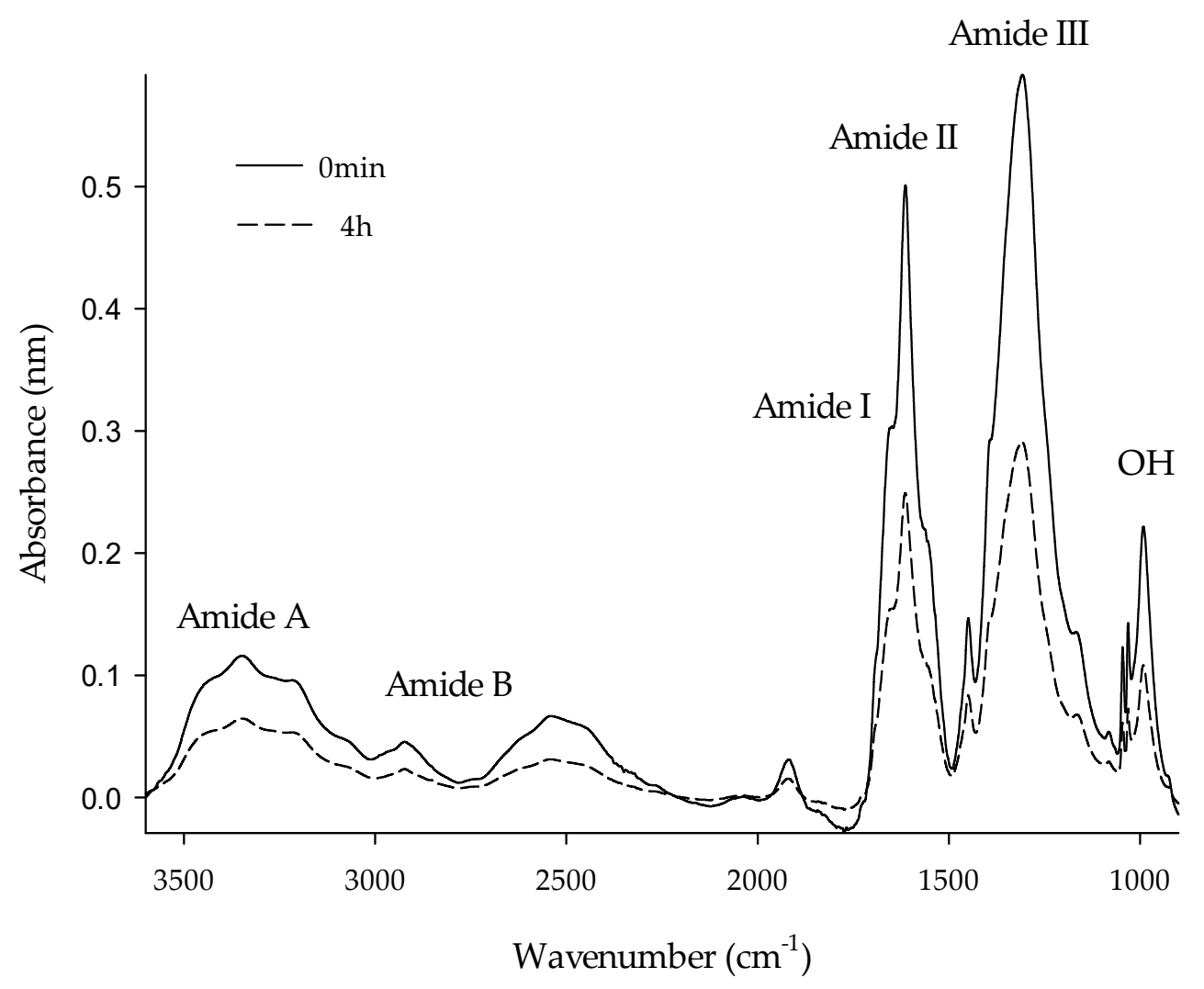

Figure 5. Fourier transform infrared spectra of collagen hydrolysates from $0 \mathrm{~min}$, and $1 \mathrm{~h}$ of hydrolysis time.

\subsection{Antioxidant Activity}

2,2' -azino-bis(3-ethylbenzothiazoline-6-sulphonic acid) (ABTS) and 2,2-diphenyl-1-picrylhydrazyl (DPPH) assays are methods frequently used in the evaluation of radical scavengers to assess the antioxidant capacity of compounds. The ABTS radical can be applied in a wide range of $\mathrm{pH}$, and is soluble in aqueous and organic media. It allows for the evaluation of both hydrophilic and lipophilic antioxidants $[53,54]$. DPPH radical is one of the most stable free radicals. It is a simple and quick method that can be used to test the ability of compounds to act as free radical scavengers or hydrogen donors [55]. The antioxidant activity of hydrolysed collagen (HC) was evaluated by the ABTS and DPPH methods as shown in Figure 6. There were differences $(p<0.05)$ between the ABTS and DPPH radical scavenging activities. The highest ABTS and DPPH radical scavenging activity was 
found at $4 \mathrm{~h}$ of hydrolysis with $67.6 \%$ and $52.75 \%$, respectively. The ABTS technique reported higher values compared to DPPH. ABTS radical scavenging is commonly used to evaluate the ability of antioxidants to donate an electron or hydrogen atom to stabilize radicals [56]. The antioxidant activity of protein hydrolysates seemed to be affected by the amino acid composition as well as the degree of hydrolysis [33]. The longer the time, the higher the antioxidative activity was observed. It is well known that several amino acids like tyrosine, histidine [57] and lysine possess antioxidant properties [43]. Also, some hydrophobic amino acids like isoleucine and methionine could donate electrons or hydrogen, converting the radical to a more stable species and contributing to higher radical scavenging [58]. The amino acid content results of this research showed that strong hydrolysis $(4 \mathrm{~h})$ of collagen from sheepskin increased the concentration of these amino acids. At this time $(4 \mathrm{~h})$, the radical scavenging activity increased significantly because there was an increment of glutamic acid from 7.99 to $16.58 \mathrm{mg} / \mathrm{g}$ of protein. On the other hand, the enzymatic treatment of native collagen decreased its $\mathrm{Mw}$ by around $6 \mathrm{KDa}$. Previous works carried out with different sources such as fish [6,8] and squid [59] showed that Mw was one of the most important parameters that determined the biological activity of collagen [60]. The lower the Mw polypeptides, the higher the antioxidant activity was found to be. These results suggested that hydrolysis of collagen generated a wide variety of smaller peptides and free amino acids depending on the hydrolysis time [61]. Therefore, the composition of amino acid content, degree of hydrolysis and size of collagen chains and source of raw material could define the antioxidant capacity of the HC.

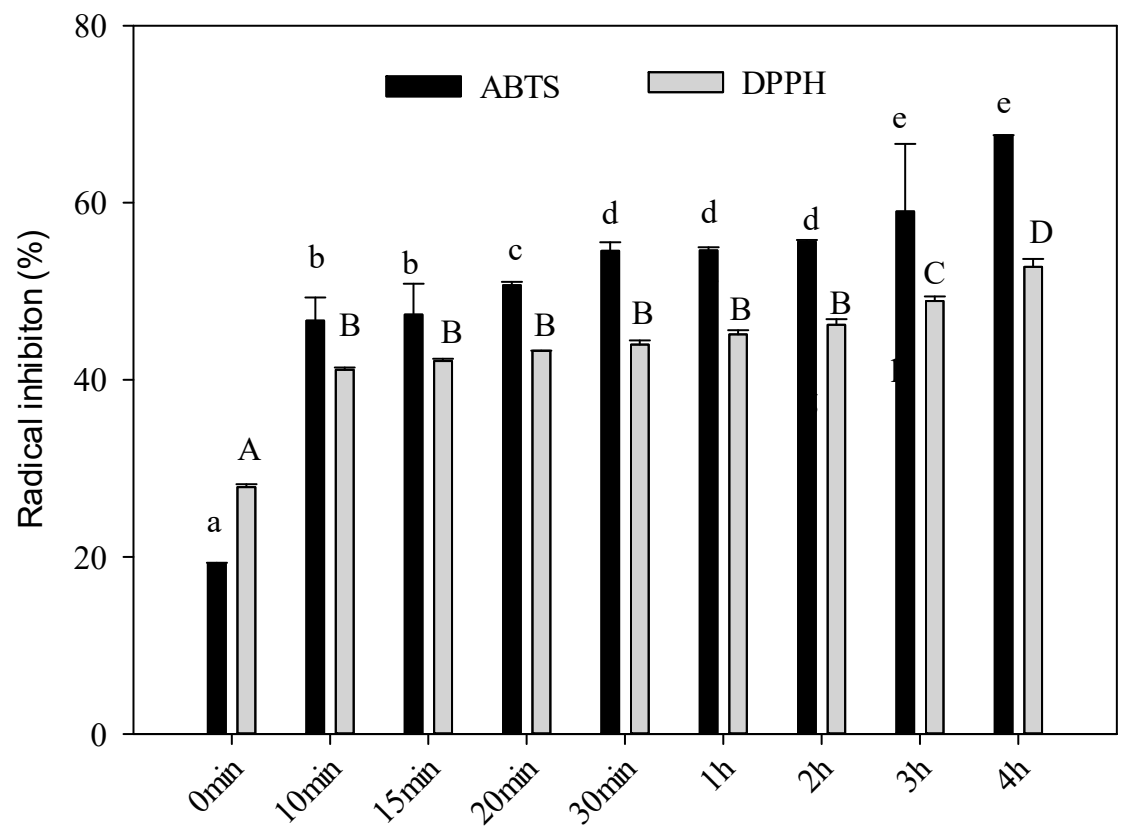

Hydrolysis time

Figure 6. Antioxidant capacity of ovine collagen during hydrolysis. The activity was evaluated with TBS and DPPH methods. Values are expressed as the mean \pm SD $(n=3)$. Different letters indicate significant difference at $p \leq 0.05$. 


\subsection{Thermal Properties}

The thermal properties of hydrolysed collagen was evaluated in dried powder with $0 \%$ of water content (d.b.) from samples obtained after different hydrolysis times. From Table 2, it can be seen that the melting temperature $(\mathrm{Tm})$ reduced gradually from $153.3^{\circ} \mathrm{C}(0 \mathrm{~min})$ to $136.9^{\circ} \mathrm{C}$ as the hydrolysis time increased up to $4 \mathrm{~h}$. This reduction in Tm suggested that the thermal stability of the triple helical structure of collagen was affected after $1 \mathrm{~h}$ of thermal and enzymatic treatment $\left(137.2^{\circ} \mathrm{C}\right)$. It is well known that intermolecular helix formation is dependent on the molecular weight $(\mathrm{Mw})$ of alpha chains [62]. The higher the Mw, the higher the Tm values that will be observed. The Tm results suggested that intermolecular helix formation reduced significantly as hydrolysis took place. This reduction originated at the bimolecular nucleation stage, which involved an intramolecular $\beta$-turn facilitated by glycine and/or proline residues [63]. This means that propagation was far less effective compared with native collagen at $0 \mathrm{~min}$ of treatment. The DSC thermograms of this native collagen showed a narrow melting range, suggesting a more homogenous population of longer helical segments. However, as the hydrolysis process started, the samples showed a broad melting range, indicating a wide molecular weight distribution of helix lengths by shifting the Tm towards lower values.

Table 2. Thermal properties of dried hydrolysed collagen powder at different times of hydrolysis. Average value of three replicates. Values followed by different letters are significantly different according to Tukey's test $(p \leq 0.05)$.

\begin{tabular}{ccc}
\hline Hydrolysis Time & $\operatorname{Tm}\left({ }^{\circ} \mathbf{C}\right)$ & $\Delta \mathbf{H}(\mathbf{J} / \mathbf{g})$ \\
\hline $0 \mathrm{~min}$ & $153.38 \pm 0.40^{\mathrm{a}}$ & $20.06 \pm 0.10^{\mathrm{a}}$ \\
$15 \mathrm{~min}$ & $147.97 \pm 0.80^{\mathrm{a}}$ & $17.21 \pm 0.47^{\mathrm{ab}}$ \\
$20 \mathrm{~min}$ & $147.72 \pm 0.45^{\mathrm{a}}$ & $17.48 \pm 0.18^{\mathrm{ab}}$ \\
$30 \mathrm{~min}$ & $147.59 \pm 0.78^{\mathrm{a}}$ & $16.91 \pm 0.32^{\mathrm{ab}}$ \\
$1 \mathrm{~h}$ & $137.91 \pm 0.35^{\mathrm{b}}$ & $15.61 \pm 0.21^{\mathrm{ab}}$ \\
$2 \mathrm{~h}$ & $137.77 \pm 0.13^{\mathrm{b}}$ & $11.46 \pm 0.49^{\mathrm{ab}}$ \\
$3 \mathrm{~h}$ & $137.24 \pm 0.37^{\mathrm{b}}$ & $9.09 \pm 0.20^{\mathrm{ab}}$ \\
$4 \mathrm{~h}$ & $136.91 \pm 0.55^{\mathrm{b}}$ & $8.93 \pm 0.11^{\mathrm{b}}$ \\
\hline
\end{tabular}

Considering the enthalpy as the energy required to disorganize the helical structure, it was possible to assume that native collagen possessed a more ordered structure $(20.06 \mathrm{~J} / \mathrm{g})$. However, hydrolysis treatment produced low molecular weight residues with a low possibility of intramolecular refolding. In fact, previous work [63] has suggested a limit of 40-80 amino acid residues as the critical size of nuclei for renaturation. Also, we have seen that samples with $\mathrm{Mw}<15 \mathrm{KDa}$ cannot recover their helical conformation even at high concentrations [64]. Enthalpy of samples with $4 \mathrm{~h}$ of hydrolysis showed significant differences $(p<0.05)$ with the lowest degree of reorganization $(8.93 \mathrm{~J} / \mathrm{g})$. However, it still showed some energy requirements to disorganize its structure. This structural conformation could be due to the intermolecular interaction of two or three strands with low Mw [64].

\subsection{SEM Images}

The morphological appearance of native collagen and their resulting hydrolysates are shown in Figure 7. It can be seen that HC showed changes in morphology across the different hydrolysis times. During the first $20 \mathrm{~min}$ of hydrolysis, the collagen did not appear to have pores in its structure (Figure 7a-c). However, after $30 \mathrm{~min}$ of treatment (Figure 7d-f), initial degradation of collagen was seen in the form of small pores in the protein structure, the result of enzymatic action leading to a partial disassembly of fibres into fibrils, and therefore, the generation of low molecular weight polypeptides. 


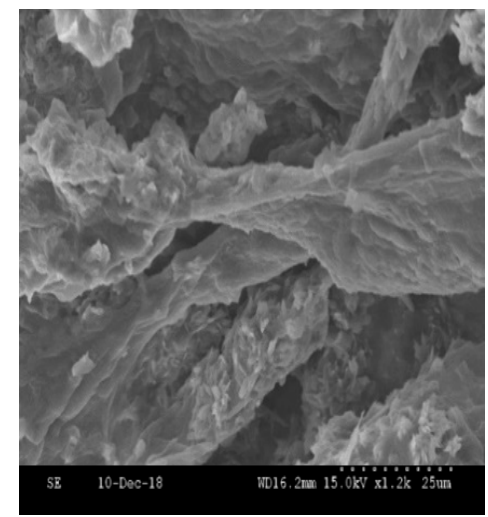

(a)

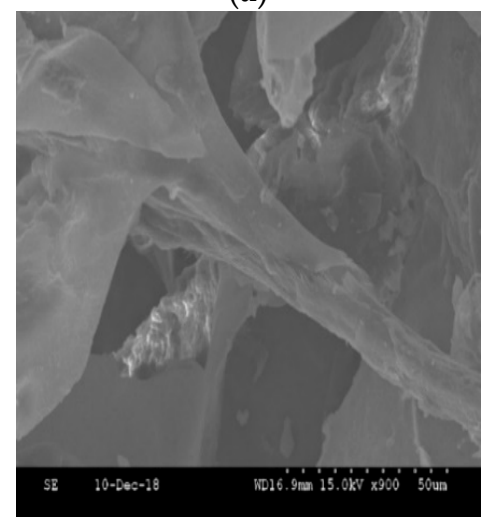

(d)

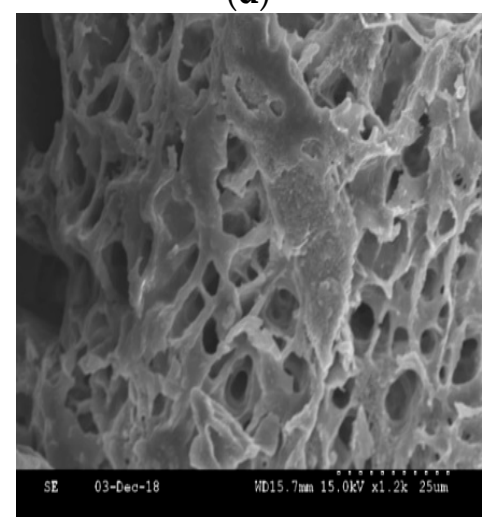

(g)

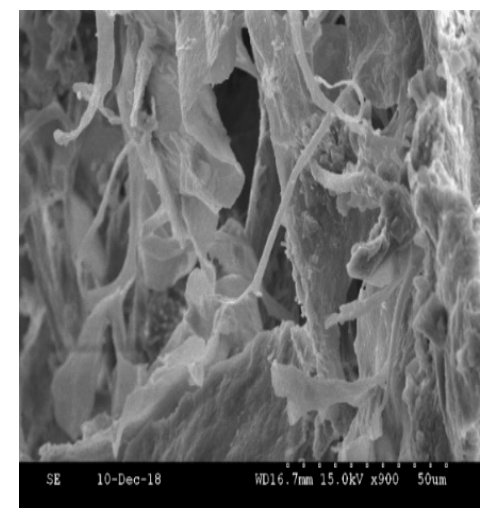

(b)

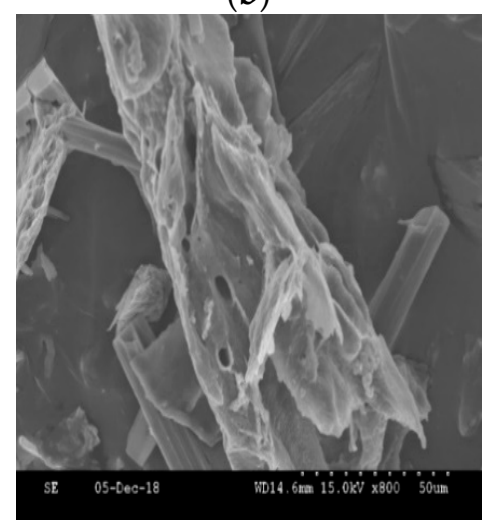

(e)

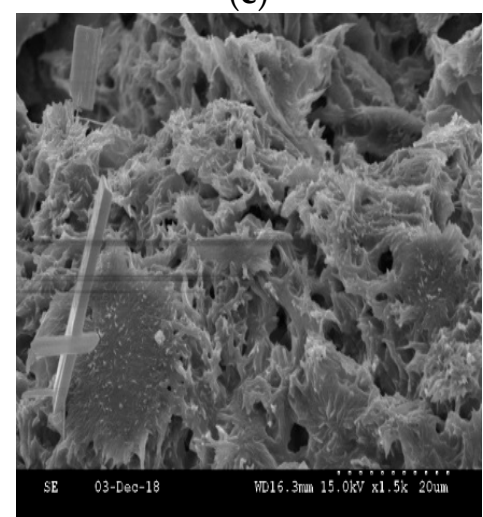

(h)

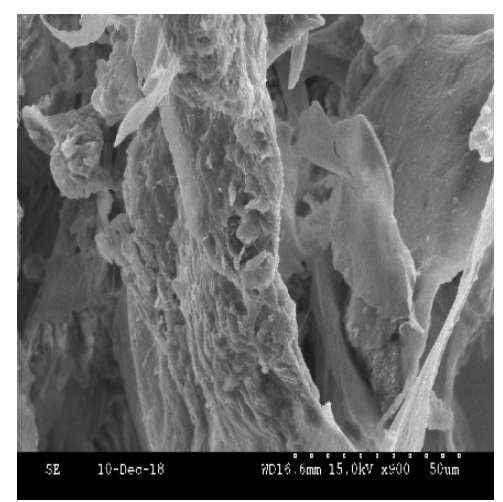

(c)

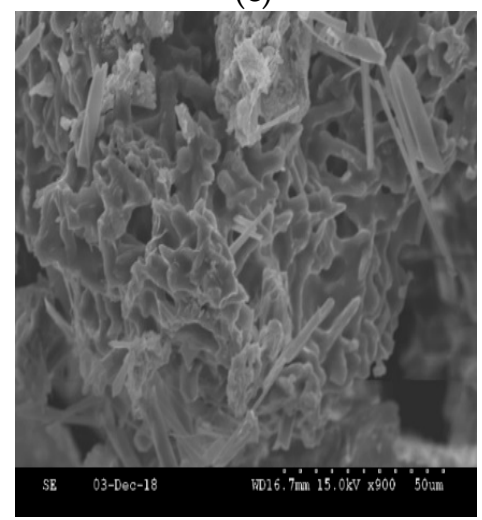

(f)

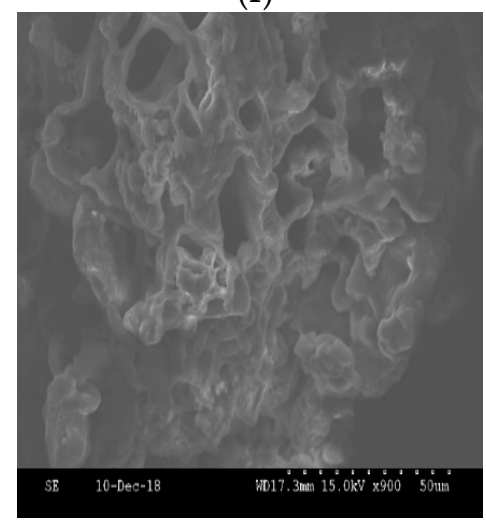

(i)

Figure 7. HC morphology changes during the hydrolysis alkaline treatment: (a) 0 min, (b) $10 \mathrm{~min}$, (c) $15 \mathrm{~min},(\mathrm{~d}) 20 \mathrm{~min},(\mathbf{e}) 30 \mathrm{~min},(\mathbf{f}) 1 \mathrm{~h},(\mathrm{~g}) 2 \mathrm{~h},(\mathbf{h}) 3 \mathrm{~h}$, (i) $4 \mathrm{~h}$.

After $2 \mathrm{~h}$ of enzymatic hydrolysis (Figure 7h,i), the disaggregation of collagen fibrils within the collagen fibres was evidence of the autolysis of the enzymatic treatment [7]. The collagen structure of these treatments (after $3 \mathrm{~h}$ and $4 \mathrm{~h}$ ) appeared to be extremely degraded, with a spongy and porous form. Previous works carried out with marine sources [65] discovered that the Mw of peptides influences the properties of HC. The lower the Mw, the more pores there are, and the more open the structure observed in the images.

\subsection{Relationship between Mw, Viscosity, Antioxidant Activity and Thermal Properties}

The properties of HC mainly appeared to obey the Mw of polypeptide chains obtained after hydrolysis. However, a strong relationship was observed with the other parameters evaluated; viscosity was closely related to Mw because these results suggested that the low Mw of polypeptide chains 
produced a low hydrodynamic volume of collagen molecules in solution [42]. This could be why the viscosity dropped to close to $0 \mathrm{Cp}$ after $1 \mathrm{~h}$ of hydrolysis. The antioxidant activity also appeared to be dependent on the Mw parameter. The results from this research showed that the lower the Mw, the higher the antioxidant activity of HC. This behaviour was confirmed by the higher concentrations of hydroxyproline after $1 \mathrm{~h}$ of hydrolysis. Additionally, higher concentrations of aspartic acid and glutamic acid were obtained over the same period of time. The measurement of thermal properties in HC indicated that low-Mw samples ( $2 \mathrm{~h}, 3 \mathrm{~h}$ and $4 \mathrm{~h}$ ) resulted in the lowest enthalpy. This means that less energy was required to disorganize the structure of $\mathrm{HC}$ because its low Mw avoided the organization into a triple helical form [66].

\section{Materials and Methods}

Sheepskins with $40-50 \%$ water content were used in this experiment. They were obtained as byproducts from a local market in Tulancingo, Hidalgo, Mexico. Reactive grade acetic acid ( $99 \%$ purity), sodium chloride reactive grade, porcine digestive protease (pepsin), dialysis membrane tubing with 6-8 kDa molecular weight cut-off, 4-dimethylaminobenzaldehyde at $5 \%, 65 \%$, perchloric acid, $0.006 \mathrm{M}$ chloramine T, 0.8 M and citrate buffer were purchased from Sigma-Aldrich Corp. (MA, USA).

\subsection{Conditioning of The Skin before Collagen Extraction}

The sheepskins were soaked to recover up to $70 \%$ water, followed by a fleshing process to remove the connective tissue and fat. Then, the skins were shaved to remove most of the hair.

\subsection{Collagen Extraction from Ovine Skin}

The methodology of Chuaychan et al. [67] was used, with some modifications. Pre-treated sheepskin was cut into small squares of approximately $1 \mathrm{~cm}^{2}$ and suspended in $0.5 \mathrm{M}$ acetic acid solution at a ratio of 1:10 (w/v). The sample was placed in a shaker machine (Bellco Biotechnology. $\mathrm{NJ}, \mathrm{USA})$ at $140 \mathrm{rpm}$ for $3 \mathrm{~h}$ at room temperature $\left(20 \pm 2{ }^{\circ} \mathrm{C}\right)$, followed by the addition of pepsin at a concentration of $1 \mathrm{~g} / \mathrm{L}$ with gentle stirring for $48 \mathrm{~h}$. The sample was filtered and precipitated with a solution of $2.6 \mathrm{M}$ sodium chloride. The precipitated material was centrifuged for $15 \mathrm{~min}$ at a relative centrifugal force of $3380 \times g$ in a centrifuge model Z36HK (HERMLE Labortechnik GmbH, Wehingen, Germany).

\subsection{Hydrolysis of Collagen}

Precipitated collagen was re-suspended in a solution of $1 \mathrm{M} \mathrm{NaCO}_{3}$ at a ratio of 1:4 $(w / v)$. The $\mathrm{pH}$ was adjusted to $8 \pm 0.2$. The hydrolysis of collagen was carried out with the enzyme trypsin at a concentration of $1: 50(w / v)$ in a water bath at $60^{\circ} \mathrm{C}$ for different times, as follows: $10 \mathrm{~min}, 15 \mathrm{~min}$, $20 \mathrm{~min}, 30 \mathrm{~min}, 1 \mathrm{~h}, 2 \mathrm{~h}, 3 \mathrm{~h}$ and $4 \mathrm{~h}$. The control sample was called $0 \mathrm{~min}$. All the samples were inactivated at $90^{\circ} \mathrm{C}$ for $10 \mathrm{~min}$ and stored at $4{ }^{\circ} \mathrm{C}$.

\subsection{Protein Determination}

Following Bradford determination [68], $5 \mathrm{~mL}$ of Bradford reagent and $100 \mu \mathrm{L}$ of the sample were added and mixed in a vortex for $2 \mathrm{~min}$. After $5 \mathrm{~min}$ storage in darkness, the sample was read in a spectrophotometer at $595 \mathrm{~nm}$. The serum albumin at different concentrations was used to create a calibration curve.

\subsection{Isoelectric Point}

The isoelectric point was measured by using a Zetasizer nano ZS90 coupled to auto-titrator MPT-2. Laser Doppler and a DTS1070 cell (Worcestershire, UK) were used to determinate the electrophoretic mobility. $\mathrm{HC}$ was diluted in distilled water at 1:10. Different values of $\mathrm{pH}$ from 2 to 7 were obtained by using $0.5 \mathrm{M} \mathrm{HCl}$ and $0.75 \mathrm{M} \mathrm{NaOH}$ buffers, respectively. 


\subsection{Hydroxyproline Quantification}

According to the AOAC methodology [69], $4 \mathrm{~g}$ of the sample and $30 \mathrm{~mL}$ of $3.5 \mathrm{M}$ sulphuric acid were placed in an oven at $105^{\circ} \mathrm{C}$ for $12 \mathrm{~h}$. The volume was adjusted to $500 \mathrm{~mL}$ with distilled water and filtered. Two millilitres of filtered sample were mixed with $1 \mathrm{~mL}$ of oxidant solution $(0.006 \mathrm{M}$ chloramine $\mathrm{T}$ in $0.8 \mathrm{M}$ citrate buffer, $\mathrm{pH}$ 6.0) in a reaction tube. The volume was adjusted to $100 \mathrm{~mL}$ and stirred for $30 \mathrm{~min}$ at room temperature. Two millilitres of colour reagent $(10 \mathrm{~g}$ of dimethylamine benzaldehyde in $35 \mathrm{~mL}$ of $65 \%$ perchloric acid) were added with stirring at $60{ }^{\circ} \mathrm{C}$ for $15 \mathrm{~min}$. The absorbance of samples was measured against the blank at $558 \mathrm{~nm}$ in a UV-visible Jenway Genova, (Bibby Scientific, Staffordshire UK) spectrophotometer.

The collagen content was calculated with the next equation:

$$
\% \text { Hydroxyproline }=\frac{(Y)(2.5)}{(W)(V)},
$$

where:

$Y=$ Hydroxyproline concentration from the standard curve

$W=$ sample weight

$V=$ volume in $\mathrm{mL}$ to adjust the $100 \mathrm{~mL}$

\subsection{Viscosity Analysis}

Viscosity measurement was carried out using a viscometer Brookfield RTV (MA, USA) (spindle number: 5; speed of $100 \mathrm{rpm})$. Viscosity was expressed in centipoise (cP). All the samples were previously conditioned at $7^{\circ} \mathrm{C}[70]$.

\subsection{Molecular Weight}

The sodium dodecyl sulphate polyacrylamide gel electrophoresis (SDS-PAGE) determination was performed according to Laemmli methodology [71]. One millilitre of dialyzed collagen was dissolved in $0.5 \mathrm{M}$ Tris- $\mathrm{HCl}$ buffer $\mathrm{pH} 6.8$ ( $1 \%$ SDS, 10\% glycerol and $0.01 \%$ bromophenol blue) and boiled for $5 \mathrm{~min}$. Then, $10 \mu \mathrm{L}$ of the denatured sample and $5 \mu \mathrm{L}$ of a marker with a molecular weight from $10 \mathrm{kDa}$ to $220 \mathrm{kDa}$ (BenchMark Protein Ladder, Thermo Scientific, Pierce ${ }^{\mathrm{TM}}$, MA, USA) were loaded into wells at the top of the polyacrylamide gel. This gel contained a $4 \%$ stacking gel on top of the $12.5 \%$ resolving gel. A voltage of $50 \mathrm{~V}$ was applied for $30 \mathrm{~min}$, and once the mobility of the proteins reached the resolving layer, the voltage was increased to $100 \mathrm{~V}$ for $4 \mathrm{~h}$ in order to see the separation of proteins according to size. As the electric current ran through the buffer, the negatively charged proteins migrated towards the anode and lower molecular weight proteins reached the bottom of the gel. After the migration of proteins, the gel was stained with Silver Stain Kit (Thermo Scientific, Pierce $^{\mathrm{TM}}$ MA, USA).

\subsection{Fourier Transform-Infrared (FTIR) Spectroscopy}

The FTIR technique offers a green alternative because it allows us to quantify substances without organic solvents. The samples do not require any pretreatment, thus reducing the environmental damage caused by toxic waste. Also, it is a fast technique based on the natural vibrational frequencies of the chemical bonds present in molecules. FTIR is a non-destructive technique using a minimum amount of sample [72]. The absorption spectra by the FTIR technique were obtained with the Frontier FT-MIR (Perkin Elmer. MA, USA) equipment. The wavelength ranged from 380 to $4000 \mathrm{~cm}^{-1}$ at room temperature. The samples were brought into intimate contact with the diamond crystal by applying a loading pressure. For each sample, the spectrum represented an average of four scans with $4 \mathrm{~cm}^{-1}$ resolution. A spectrum of the empty cell was used as the background. Automatic signals were collected 
in 3620 scans at $1 \mathrm{~cm}^{-1}$ resolution. All the data were processed with Spectrum ${ }^{\mathrm{TM}} 10$ (Perkin Elmer. MA, USA) software.

\subsection{Differential Scanning Calorimetry (DSC)}

Thermal properties of HC were obtained with DSC series Q 2000 with intracooler RCS90 (DE, USA). It was calibrated with indium (Tm, onset $\frac{1}{4} 156.68 \mathrm{C}, \Delta \mathrm{H} \frac{1}{4} 28.45 \mathrm{~J} / \mathrm{g}$ ). An average of $1.5 \pm 0.1 \mathrm{mg}$ of sample with known water content $(0 \% \mathrm{db})$ was packed and hermetically sealed in a $50-\mathrm{mL}$ stainless steel pan. An empty, hermetically sealed pan was used for a reference. Both heating and cooling scan rates were performed at $10^{\circ} \mathrm{C} / \mathrm{min}$. Two heating scans were performed from $25^{\circ} \mathrm{C}$ to $120^{\circ} \mathrm{C}$. Melting point temperature $(\mathrm{Tm})$ and enthalpy $(\Delta \mathrm{H})$ were determined with TA 2000 analysis software (TA Instruments, DE, USA) based on the endothermic changes registered in the thermogram.

\subsection{Amino Acid Determination}

Amino acid content determination was performed according to Cohen [73] with some modifications. Three milligrams of freeze-dried $\mathrm{HC}$ were suspended in $6 \mathrm{M} \mathrm{HCl}$ and $1 \% v / v$ phenol at $150{ }^{\circ} \mathrm{C}$ for $1 \mathrm{~h}$. Hydrolysed samples were dissolved in $2 \mathrm{~mL}$ of $0.5 \mathrm{M}$ citrate buffer. Amino acid content was determined by high-performance liquid chromatography (HPLC) in a Hewlett Packard model GmbH (Winchester, UK) connected to a fluorescence detector (Ex. $250 \mathrm{Em}$. 395). The derivation reaction was carried out with $20 \mu \mathrm{L}$ of the sample diluted in $60 \mu \mathrm{L}$ buffer (borate buffer, Waters, Thermo Scientific, Pierce $^{\mathrm{TM}}$, MA, USA) and 1 min stirring. Twenty microlitres of reagent AQC (Waters) were added with stirring for another $1 \mathrm{~min}$, followed by the heating of the sample at $50{ }^{\circ} \mathrm{C}$ for $10 \mathrm{~min}$. The amino acid separation was carried out in a Bluespherßcolumn $(100 \times 2 \mathrm{~mm}$ ID) in reverse phase C18 octa-decyl dimethylsilane (Berlin, Germany). Conditions of work: mobile phase A: $50 \mathrm{mM}$ sodium acetate, pH 5.75 and mobile phase B: $50 \mathrm{mM}$ sodium acetate, pH 6/CAN 30:70 v/v, and $1 \mathrm{~mL} / \mathrm{min}$ flow.

\subsection{Antioxidant Activity}

A solution of 2,2'-azino-bis(3-ethylbenzothiazoline-6-sulphonic acid) (ABTS) radical was prepared according to the literature [74] by mixing $7 \mathrm{mM}$ ABTS and $2.45 \mathrm{mM}$ potassium persulfate. After $16 \mathrm{~h}$ of stirring at room temperature in the dark, the ABTS solution was diluted with ethanol to stabilize it to $0.70 \pm 0.02$ at $734 \mathrm{~nm}$. One millilitre of stabilized ABTS solution was mixed with $0.2 \mathrm{~mL}$ of the sample and the absorbance raised to $734 \mathrm{~nm}$ in a UV-visible Jenway Genova (Bibby Scientific, Staffordshire UK) spectrophotometer.

For assessing the antioxidant activity by 2,2-diphenyl-1-picrylhydrazyl (DPPH) radical inhibition [75], $0.5 \mathrm{~mL}$ of the sample was mixed with $2.5 \mathrm{~mL}$ of $6.1 \times 10^{-5} \mathrm{M}$ methanolic radical DPPH solution and maintained in darkness for $30 \mathrm{~min}$. The absorbance was measured at $515 \mathrm{~nm}$ in a UV-visible Jenway Genova spectrophotometer. The antioxidant activity for ABTS and DPPH radical inhibition was calculated via the following equation:

$$
\% \text { Inhibition }=\frac{\text { Initial absorbance }- \text { Final absorbance }}{\text { Initial absorbance }} \times 100
$$

\subsection{Scanning Electron Microscopy (SEM)}

Morphology analysis was observed by a scanning electron microscope (Model S-2600N, HITACHI, Tokio, Japan). Freeze-dried HC samples were mounted on a strip of self-adhesive carbon paper and sputter-coated with gold to be observed in the scanning electron microscope at an acceleration voltage of $15 \mathrm{kV}$. 


\subsection{Statistical Analysis}

A randomized design experiment and an analysis of variance (ANOVA) were applied to the experimental data, which included a Tukey test $(p \leq 0.05)$. Data were analysed with SPSS 16.0 software (SPSS Inc., Chicago, IL, USA). Three replicates per treatment were considered in this experiment.

\section{Conclusions}

The study demonstrated that sheepskins are a good source of hydrolysed collagen. The best results were seen after $2 \mathrm{~h}$ of hydrolysis treatment. From this point, the kinetics of native collagen hydrolysis produced polypeptides with a low molecular weight and viscosity. This reduction in the polypeptide chain size affected the thermal properties of $\mathrm{HC}$ as the $4 \mathrm{~h}$ treatment produced a lower enthalpy value. Also, the antioxidant properties of $\mathrm{HC}$ were enhanced as the hydrolysis time increased. The functional properties of $\mathrm{HC}$ could be controlled by the hydrolysis time and sheepskins appeared to be a good alternative to typical sources like pigs, cows and fish.

Author Contributions: Conceptualization, R.G.C.-M and G.A.-Á.; Data curation, A.D.H.-F and R.G.C.-M.; Formal analysis, A.D.H.-F, R.G.C.-M and G.A-A; Investigation, A.L.-L and L.F.-J; Methodology, A.L.-L; Supervision, G.A.-A; Writing—original draft, A.L.-L; Writing—review \& editing, G.A.-A.

Funding: This research was funded by CONACyT, grant number 621400.

Acknowledgments: The first author gratefully acknowledges Dimitrios Zeugolis for his technical support during a research stay at the University of Galway, Ireland.

Conflicts of Interest: The authors declare no conflict of interest.

\section{Abbreviations}

$\begin{array}{ll}\text { HC } & \text { Hydrolysed collagen } \\ \text { SDS-PAGE } & \text { Sodium dodecyl sulphate polyacrylamide gel Electrophoresis } \\ \text { Mw } & \text { Molecular weight } \\ \text { FTIR } & \text { Fourier transform-infrared spectroscopy } \\ \text { DSC } & \text { Differential scanning calorimetry } \\ \text { DPPH } & \text { 2,2-diphenyl-1-picrylhydrazyl } \\ \text { ABTS } & \text { 2,2'-azino-bis, 3-ethylbenzothiazoline-6-sulphonic acid } \\ \text { ANOVA } & \text { Analysis of variance } \\ \text { SEM } & \text { Scanning electron microscopy }\end{array}$

\section{References}

1. Gao, L.-L.; Wang, Z.-Y.; Li, Z.; Zhang, C.-X.; Zhang, D.-Q. The characterization of acid and pepsin soluble collagen from ovine bones (Ujumuqin sheep). J. Integr. Agric. 2018, 17, 704-711. [CrossRef]

2. Liu, D.; Liang, L.; Regenstein, J.M.; Zhou, P. Extraction and characterisation of pepsin-solubilised collagen from fins, scales, skins, bones and swim bladders of bighead carp (Hypophthalmichthys nobilis). Food Chem. 2012, 133, 1441-1448. [CrossRef]

3. Rodriguez, M.I.A.; Barroso, L.G.R. Sanchez, M.L. Collagen: A review on its sources and potential cosmetic applications. J. Cosmet. Dermatol. 2018, 17, 20-26. [CrossRef] [PubMed]

4. Choi, D.; Min, S.G.; Jo, Y.J. Functionality of porcine skin hydrolysates produced by hydrothermal processing for liposomal delivery system. J. Food Biochem. 2018, 42, e12464. [CrossRef]

5. O'Sullivan, S.M.; Lafarga, T.; Hayes, M.; O'Brien, N.M. Bioactivity of bovine lung hydrolysates prepared using papain, pepsin, and Alcalase. J. Food Biochem. 2017, 41, e12406. [CrossRef]

6. Benjakul, S.; Karnjanapratum, S.; Visessanguan, W. Production and Characterization of Odorless Antioxidative Hydrolyzed Collagen from Seabass (Lates calcarifer) Skin without Descaling. Waste Biomass Valori. 2018, 9, 549-559. [CrossRef]

7. Liu, Z.Q.; Tuo, F.Y.; Song, L.; Liu, Y.X.; Dong, X.P.; Li, D.M.; Zhou, D.Y.; Shahidi, F. Action of trypsin on structural changes of collagen fibres from sea cucumber (Stichopus japonicus). Food Chem. 2018, 256, 113-118. [CrossRef] 
8. Wu, R.; Wu, C.; Liu, D.; Yang, X.; Huang, J.; Zhang, J.; Liao, B.; He, H. Antioxidant and anti-freezing peptides from salmon collagen hydrolysate prepared by bacterial extracellular protease. Food Chem. 2018, 248, 346-352. [CrossRef]

9. Martínez-Ortiz, M.A.; Hernández-Fuentes, A.D.; Pimentel-González, D.J.; Campos-Montiel, R.G.; Vargas-Torres, A.; Aguirre-Álvarez, G. Extraction and characterization of collagen from rabbit skin: Partial characterization. Cyta J. Food 2015, 13, 253-258. [CrossRef]

10. Sibilla, S.; Godfrey, M.; Brewer, S.; Budh-Raja, A.; Genovese, L. An Overview of the Beneficial Effects of Hydrolysed Collagen as a Nutraceutical on Skin Properties: Scientific Background and Clinical Studies. Open Nutraceuticals J. 2015, 8, 29-42. [CrossRef]

11. Bilek, S.E.; Bayram, S.K. Fruit juice drink production containing hydrolyzed collagen. J. Funct. Foods 2015, 14, 562-569. [CrossRef]

12. Denis, A.; Brambati, N.; Dessauvages, B.; Guedj, S.; Ridoux, C.; Meffre, N.; Autier, C. Molecular weight determination of hydrolyzed collagens. Food Hydrocoll. 2008, 22, 989-994. [CrossRef]

13. Wang, Y.; Zhang, C.-1.; Zhang, Q.; Li, P. Composite electrospun nanomembranes of fish scale collagen peptides/chito-oligosaccharides: antibacterial properties and potential for wound dressing. Int J Nanomed. 2011, 6, 667-676.

14. Moskowitz, R.W. Role of collagen hydrolysate in bone and joint disease. Semin. Arthritis Rheum. 2000, 30, 87-99. [CrossRef] [PubMed]

15. Schrieber, R.; Gareis, H. Gelatine Handbook: Theory and Industrial Practice; John Wiley \& Sons: Hoboken, NJ, USA, 2007.

16. Zague, V. A new view concerning the effects of collagen hydrolysate intake on skin properties. Arch. Dermatol. Res. 2008, 300, 479-483. [CrossRef] [PubMed]

17. Zhang, Z.; Li, G.; Shi, B. Physicochemical properties of collagen, gelatin and collagen hydrolysate derived from bovine limed split wastes. J. Soc. Leather Technol. Chem. 2006, 90, 23.

18. Lorenzo, J.M.; Munekata, P.E.S.; Gomez, B.; Barba, F.J.; Mora, L.; Perez-Santaescolastica, C.; Toldra, F. Bioactive peptides as natural antioxidants in food products-A review. Trends Food Sci. Technol. 2018, 79, 136-147. [CrossRef]

19. Jin, H.X.; Xu, H.P.; Li, Y.; Zhang, Q.W.; Xie, H. Preparation and Evaluation of Peptides with Potential Antioxidant Activity by Microwave Assisted Enzymatic Hydrolysis of Collagen from Sea Cucumber Acaudina Molpadioides Obtained from Zhejiang Province in China. Mar. Drugs 2019, 17, 169. [CrossRef]

20. Zhao, W.H.; Luo, Q.B.; Pan, X.; Chi, C.F.; Sun, K.L.; Wang, B. Preparation, identification, and activity evaluation of ten antioxidant peptides from protein hydrolysate of swim bladders of miiuy croaker (Miichthys miiuy). J. Funct. Foods 2018, 47, 503-511. [CrossRef]

21. Hong, G.P.; Min, S.G.; Jo, Y.J. Anti-Oxidative and Anti-Aging Activities of Porcine By-Product Collagen Hydrolysates Produced by Commercial Proteases: Effect of Hydrolysis and Ultrafiltration. Molecules 2019, 24, 1104. [CrossRef]

22. Vidal, A.R.; Ferreira, T.E.; Mello, R.D.; Schmidt, M.M.; Kubota, E.H.; Demiate, I.M.; Zielinski, A.A.F.; Dornelles, R.C.P. Effects of enzymatic hydrolysis (Flavourzyme (R)) assisted by ultrasound in the structural and functional properties of hydrolyzates from different bovine collagens. Food Sci. Technol. 2018, 38, 103-108. [CrossRef]

23. Liu, C.Y.; Ma, X.M.; Che, S.; Wang, C.W.; Li, B.F. The Effect of Hydrolysis with Neutrase on Molecular Weight, Functional Properties, and Antioxidant Activities of Alaska Pollock Protein Isolate. J. Ocean Univ. China 2018, 17, 1423-1431. [CrossRef]

24. Blanco, M.; Vazquez, J.A.; Perez-Martin, R.I.; Sotelo, C.G. Hydrolysates of Fish Skin Collagen: An Opportunity for Valorizing Fish Industry Byproducts. Mar. Drugs 2017, 15, 131. [CrossRef]

25. Pal, G.K.; Suresh, P.V. Comparative assessment of physico-chemical characteristics and fibril formation capacity of thermostable carp scales collagen. Mater. Sci. Eng. C-Mater. Biol. Appl. 2017, 70, 32-40. [CrossRef]

26. Lee, H.-J.; Chae, S.-J.; Saravana, P.S.; Chun, B.-S. Physical and functional properties of tunicate (Styela clava) hydrolysate obtained from pressurized hydrothermal process. Fish. Aquat. Sci. 2017, 20, 14. [CrossRef]

27. Felician, F.F.; Xia, C.L.; Qi, W.Y.; Xu, H.M. Collagen from Marine Biological Sources and Medical Applications. Chem. Biodivers. 2018, 15, e1700557. [CrossRef]

28. Sae-leaw, T.; Benjakul, S. Antioxidant activities of hydrolysed collagen from salmon scale ossein prepared with the aid of ultrasound. Int. J. Food Sci. Technol. 2018, 53, 2786-2795. [CrossRef] 
29. Paul, R.; Adzet, J.M.; Brouta-Agnésa, M.; Balsells, S.; Esteve, H. Hydrolyzed collagen: A novel additive in cotton and leather dyeing. Dye. Pigment. 2012, 94, 475-480. [CrossRef]

30. Offengenden, M.; Chakrabarti, S.; Wu, J. Chicken collagen hydrolysates differentially mediate anti-inflammatory activity and type I collagen synthesis on human dermal fibroblasts. Food Sci. Hum. Wellness 2018, 7, 138-147. [CrossRef]

31. Bateman, J.F.; Lamande, S.R.; Ramshaw, J.A. Collagen superfamily. Extracell. Matrix 1996, 2, $22-67$.

32. Atma, Y.; Hanifah, N.L.; Endang, P.; Hermawan, S.; Moh, T.; Dita, F.; Apon, Z.M. The hydroxyproline content of fish bone gelatin from Indonesian pangasius catfish by enzymatic hydrolysis for producing the bioactive peptide. Biofarmasi. J. Nat. Prod. Biochem. 2018, 6, 64-68.

33. Ao, J.; Li, B. Amino acid composition and antioxidant activities of hydrolysates and peptide fractions from porcine collagen. Food Sci. Technol. Int. 2012, 18, 425-434. [CrossRef] [PubMed]

34. Li-Chan, E.C.Y.; Hunag, S.L.; Jao, C.L.; Ho, K.P.; Hsu, K.C. Peptides Derived from Atlantic Salmon Skin Gelatin as Dipeptidyl-peptidase IV Inhibitors. J. Agric. Food Chem. 2012, 60, 973-978. [CrossRef]

35. Benjakul, S.; Oungbho, K.; Visessanguan, W.; Thiansilakul, Y.; Roytrakul, S. Characteristics of gelatin from the skins of bigeye snapper, Priacanthus tayenus and Priacanthus macracanthus. Food Chem. 2009, 116, 445-451. [CrossRef]

36. Gómez-Lizárraga, K.; Piña-Barba, C.; Rodríguez-Fuentes, N.; Romero, M. Obtención y caracterización de colágena tipo I a partir de tendón bovino. Superf. Y Vacío 2011, 24, 137-140.

37. Soladoye, O.P.; Saldo, J.; Peiro, L.; Rovira, A.; Mor-Mur, M. Antioxidant and Angiotensin 1 Converting Enzyme Inhibitory Functions from Chicken Collagen Hydrolysates. J. Nutr. Food Sci. 2015, 5, 1. [CrossRef]

38. Friess, W. Collagen-biomaterial for drug delivery. Eur. J. Pharm. Biopharm. 1998, 45, 113-136. [CrossRef]

39. Paschalis, E.; Verdelis, K.; Doty, S.; Boskey, A.; Mendelsohn, R.; Yamauchi, M. Spectroscopic characterization of collagen cross-links in bone. J. Bone Miner. Res. 2001, 16, 1821-1828. [CrossRef]

40. Kittiphattanabawon, P.; Benjakul, S.; Visessanguan, W.; Nagai, T.; Tanaka, M. Characterisation of acid-soluble collagen from skin and bone of bigeye snapper (Priacanthus tayenus). Food Chem. 2005, 89, 363-372. [CrossRef]

41. Wu, H.C.; Chen, H.M.; Shiau, C.Y. Free amino acids and peptides as related to antioxidant properties in protein hydrolysates of mackerel (Scomber austriasicus). Food Res. Int. 2003, 36, 949-957. [CrossRef]

42. Aguirre-Alvarez, G.; Foster, T.; Hill, S.E. Impact of the origin of gelatins on their intrinsic properties. Cyta-J. Food 2012, 10, 306-312. [CrossRef]

43. Kim, S.K.; Kim, Y.T.; Byun, H.G.; Nam, K.S.; Joo, D.S.; Shahidi, F. Isolation and characterization of antioxidative peptides from gelatin hydrolysate of Alaska pollack skin. J. Agric. Food Chem. 2001, 49, 1984-1989. [CrossRef] [PubMed]

44. Caessens, P.W.; Daamen, W.F.; Gruppen, H.; Visser, S.; Voragen, A.G. $\beta$-Lactoglobulin hydrolysis. 2. Peptide identification, $\mathrm{SH} / \mathrm{SS}$ exchange, and functional properties of hydrolysate fractions formed by the action of plasmin. J. Agric. Food Chem. 1999, 47, 2980-2990. [CrossRef] [PubMed]

45. Chalamaiah, M.; Hemalatha, R.; Jyothirmayi, T. Fish protein hydrolysates: proximate composition, amino acid composition, antioxidant activities and applications: a review. Food Chem. 2012, 135, 3020-3038. [CrossRef] [PubMed]

46. Zhang, M.; Liu, W.T.; Li, G.Y. Isolation and characterisation of collagens from the skin of largefin longbarbel catfish (Mystus macropterus). Food Chem. 2009, 115, 826-831. [CrossRef]

47. Chi, C.; Hu, F.; Li, Z.; Wang, B.; Luo, H. Influence of Different Hydrolysis Processes by Trypsin on the Physicochemical, Antioxidant, and Functional Properties of Collagen Hydrolysates from Sphyrna lewini, Dasyatis akjei, and Raja porosa. J. Aquat. Food Prod. Technol. 2016, 25, 616-632. [CrossRef]

48. Khiari, Z.; Ndagijimana, M.; Betti, M. Low molecular weight bioactive peptides derived from the enzymatic hydrolysis of collagen after isoelectric solubilization/precipitation process of turkey by-products. Poult. Sci. 2014, 93, 2347-2362. [CrossRef]

49. Yan, L.J.; Jin, T.C.; Chen, Y.L.; Zhan, C.L.; Zhang, L.J.; Weng, L.; Liu, G.M.; Cao, M.J. Characterization of a recombinant matrix metalloproteinase-2 from sea cucumber (Stichopus japonicas) and its application to prepare bioactive collagen hydrolysate. Process Biochem. 2018, 72, 63-70. [CrossRef]

50. Ogawa, M.; Portier, R.J.; Moody, M.W.; Bell, J.; Schexnayder, M.A.; Losso, J.N. Biochemical properties of bone and scale collagens isolated from the subtropical fish black drum (Pogonia cromis) and sheepshead seabream (Archosargus probatocephalus). Food Chem. 2004, 88, 495-501. [CrossRef] 
51. Pan, B.S.; Chen, H.E.; Sung, W.C. Molecular and thermal characteristics of acid-soluble collagen from orbicular batfish: effects of deep-sea water culturing. Int. J. Food Prop. 2018, 21, 1080-1090. [CrossRef]

52. Barth, A.; Zscherp, C. What vibrations tell us about proteins. Q. Rev. Biophys. 2002, 35, 369-430. [CrossRef]

53. Shalaby, E.A.; Shanab, S.M.M. Comparison of DPPH and ABTS assays for determining antioxidant potential of water and methanol extracts of Spirulina platensis. Indian J. Geo-Mar. Sci. 2013, 42, 556-564.

54. Amorati, R.; Valgimigli, L. Advantages and limitations of common testing methods for antioxidants. Free Radic. Res. 2015, 49, 633-649. [CrossRef]

55. Foh, M.B.K.; Amadou, I.; Foh, B.M.; Kamara, M.T.; Xia, W. Functionality and antioxidant properties of Tilapia (Oreochromis niloticus) as influenced by the degree of hydrolysis. Int. J. Mol. Sci. 2010, 11, 1851-1869. [CrossRef]

56. Leong, L.P.; Shui, G. An investigation of antioxidant capacity of fruits in Singapore markets. Food Chem. 2002, 76, 69-75. [CrossRef]

57. Chen, H.M.; Muramoto, K.; Yamauchi, F.; Fujimoto, K.; Nokihara, K. Antioxidative properties of histidine-containing peptides designed from peptide fragments found in the digests of a soybean protein. J. Agric. Food Chem. 1998, 46, 49-53. [CrossRef]

58. Pownall, T.L.; Udenigwe, C.C.; Aluko, R.E. Amino Acid Composition and Antioxidant Properties of Pea Seed (Pisum sativum L.) Enzymatic Protein Hydrolysate Fractions. J. Agric. Food Chem. 2010, 58, 4712-4718. [CrossRef]

59. Nam, K.A.; You, S.G.; Kim, S.M. Molecular and physical characteristics of squid (Todarodes pacificus) skin collagens and biological properties of their enzymatic hydrolysates. J. Food Sci. 2008, 73, C249-C255. [CrossRef]

60. Gómez-Guillén, M.C.; Giménez, B.; López-Caballero, M.E.; Montero, M.P. Functional and bioactive properties of collagen and gelatin from alternative sources: A review. Food Hydrocoll. 2011, 25, 1813-1827. [CrossRef]

61. Khantaphant, S.; Benjakul, S. Comparative study on the proteases from fish pyloric caeca and the use for production of gelatin hydrolysate with antioxidative activity. Comp. Biochem. Physiol. B-Biochem. Mol. Biol. 2008, 151, 410-419. [CrossRef]

62. Busnel, J.P.; Morris, E.R.; Rossmurphy, S.B. Interpretation of the renaturation kinetics of gelatin solutions. Int. J. Biol. Macromol. 1989, 11, 119-125. [CrossRef]

63. Harrington, W.F.; Rao, N.V. Collagen structure in solution. I. Kinetics of helix regeneration in single-chain gelatins. Biochemistry 1970, 9, 3714-3724. [CrossRef]

64. Djabourov, M.; Nishinari, K.; Ross-Murphy, S.B.; Djabourov, M.; Nishinari, K.; RossMurphy, S.B. Helical Structures from Neutral Biopolymers; Cambridge Univ Press: Cambridge, UK, 2013; pp. 182-221.

65. Chi, C.F.; Cao, Z.H.; Wang, B.; Hu, F.Y.; Li, Z.R.; Zhang, B. Antioxidant and functional properties of collagen hydrolysates from Spanish mackerel skin as influenced by average molecular weight. Molecules 2014, 19, 11211-11230. [CrossRef]

66. Aguirre-Alvarez, G.; Pimentel-Gonzalez, D.J.; Campos-Montiel, R.G.; Foster, T.; Hill, S.E. The effect of drying temperature on mechanical properties of pig skin gelatin films. Cyta-J. Food 2011, 9, 243-249. [CrossRef]

67. Chuaychan, S.; Benjakul, S.; Kishimura, H. Characteristics of acid- and pepsin-soluble collagens from scale of seabass (Lates calcarifer). Lwt Food Sci. Technol. 2015, 63, 71-76. [CrossRef]

68. Bradford, M.M. A rapid and sensitive method for the quantitation of microgram quantities of protein utilizing the principle of protein-dye binding. Anal. Biochem. 1976, 72, 248-254. [CrossRef]

69. AOAC Authors. Official methods of analysis Amino Acids. Analysis Acid hydrolysis Hydroxyproline-Item 77. In Food Analysis Methods, 17th ed.; Association of Analytical Communities: Gaithersburg, MD, USA, 2006; Reference data: Method 990.26 (39.1.27); NFNAP; NITR; HYP.

70. Yu, D.; Chi, C.-F.; Wang, B.; Ding, G.-F.; Li, Z.-R. Characterization of acid-and pepsin-soluble collagens from spines and skulls of skipjack tuna (Katsuwonus pelamis). Chin. J. Nat. Med. 2014, 12, 712-720. [CrossRef]

71. Laemmli, U.K. Cleavage of Structural Proteins during the Assembly of the Head of Bacteriophage T4. Nature 1970, 227, 680-685. [CrossRef]

72. Fanelli, S.; Zimmermann, A.; Totoli, E.G.; Salgado, H.R.N. FTIR Spectrophotometry as a Green Tool for Quantitative Analysis of Drugs: Practical Application to Amoxicillin. J. Chem. 2018. [CrossRef] 
73. Cohen, S.A. Amino acids analysis using precolumn derivatization with 6-Aminoquinolyl-N-Hidroxysuccinimidyl Carbamate. In Amino Acid Analysis Protocols. Methods in Molecular Biology; Cooper, C., Packer, N., Williams, K., Eds.; Humana Press: Totowa, NJ, USA, 2001; Volume 159, pp. 39-47.

74. Re, R.; Pellegrini, N.; Proteggente, A.; Pannala, A.; Yang, M.; Rice-Evans, C. Antioxidant activity applying and improve ABTS radical cation decolorization assay. Free Radic. Biol. Med. 1999, 26, 1231-1237. [CrossRef]

75. Brand-Williams, W.; Cuvelier, M.E.; Berse, C. Use of a free radical method to evaluate antioxidant activity. Lwt Food Sci. Technol. 1995, 28, 25-30. [CrossRef]

(C) 2019 by the authors. Licensee MDPI, Basel, Switzerland. This article is an open access article distributed under the terms and conditions of the Creative Commons Attribution (CC BY) license (http://creativecommons.org/licenses/by/4.0/). 